\title{
Capturing Amyloid- $\beta$ Oligomers by Stirring with Microscaled Iron Oxide Stir Bars into Magnetic Plaques to Reduce Cytotoxicity toward Neuronal Cells
}

\author{
Yuan-Chung Tsai ${ }^{1}$, Jing-Chian Luo ${ }^{1}$, Te-I Liu ${ }^{1}$, I-Lin Lu ${ }^{1,2}$, Ming-Yin Shen ${ }^{1,3}$, \\ Chun-Yu Chuang ${ }^{1}$, Chorng-Shyan Chern ${ }^{4}$ and Hsin-Cheng Chiu ${ }^{1, * \mathbb{B}}$ \\ 1 Department of Biomedical Engineering and Environmental Sciences, National Tsing Hua University, \\ Hsinchu 30013, Taiwan; smallqq_109@hotmail.com (Y.-C.T.); eric820713@hotmail.com (J.-C.L.); \\ be0007599@gmail.com (T.-I.L.); b8201130@yahoo.com.tw (I.-L.L.); mingyin.shen@gmail.com (M.-Y.S.); \\ cychuang@mx.nthu.edu.tw (C.-Y.C.) \\ 2 Department of Surgery, Hsinchu Mackay Memorial Hospital, Hsinchu 30071, Taiwan \\ 3 Department of Surgery, China Medical University Hospital-Hsinchu Branch, Hsinchu 30059, Taiwan \\ 4 Department of Chemical Engineering, National Taiwan University of Science and Technology, Taipei 10607, \\ Taiwan; cschern@mail.ntust.edu.tw \\ * Correspondence: hscchiu@mx.nthu.edu.tw; Tel.: +886-3-5715131 (ext. 34233)
}

Received: 29 April 2020; Accepted: 28 June 2020; Published: 30 June 2020

\begin{abstract}
Soluble amyloid- $\beta$ oligomers $\left(\mathrm{oA} \beta_{42}\right)$-induced neuronal death and inflammation response has been recognized as one of the major causes of Alzheimer's disease (AD). In this work, a novel strategy adopting silica-coated iron oxide stir bar (MSB)-based AD therapy system via magnetic stirring-induced capture of $\mathrm{oA} \beta_{42}$ into magnetic plaques $\left(\mathrm{mpA} \beta_{42}\right)$ and activation of microglia on cellular plaque clearance was developed. With oA $\beta_{42}$ being effectively converted into mpA $\beta_{42}$, the neurotoxicity toward neuronal cells was thus greatly reduced. In addition to the good preservation of neurite outgrowth through the diminished uptake of $\mathrm{oA} \beta_{42}$, neurons treated with oA $\beta_{42}$ under magnetic stirring also exhibited comparable neuron-specific protein expression to those in the absence of $\mathrm{oA} \beta_{42}$. The phagocytic uptake of $\mathrm{mpA} \beta_{42}$ by microglia was enhanced significantly as compared to the counterpart of $\mathrm{oA} \beta_{42}$, and the M1 polarization of microglia often occurring after the uptake of $\mathrm{oA} \beta_{42}$ restricted to an appreciable extent. As a result, the inflammation induced by pro-inflammatory cytokines was greatly alleviated.
\end{abstract}

Keywords: Alzheimer's disease; amyloid beta-peptides; microglial cell polarization; microscaled stirring; magnetic stir bars

\section{Introduction}

The abnormal accumulation of amyloid- $\beta$ oligomers $\left(\mathrm{oA} \beta_{42}\right)$ and protofibrils within neuronal/ microglial cells is believed to be crucial to Alzheimer's disease (AD) progression [1]. Although new strategies in therapeutic regimens including $\beta$-secreatase 1 (BACE1) inhibition, $\gamma$-secretase suppression, and passive anti-amyloid- $\beta$ immunotherapies [2,3] have been proposed, the efficacy is still not significant probably due to the incomplete elimination of $\mathrm{oA} \beta_{42}$ species in brain. For instance, an oral BACE1 inhibitor, Lanabecestat, was discontinued in phase III clinical study owing to its insignificant therapeutic efficacy [4]. A passive anti-amyloid- $\beta$ antibody drug, solanezumab, was failed in clinical trial due to the poor improvement on cognitive impairment [5]. In addition to the neurotoxicity of oA $\beta_{42}$ from the impairment of synaptic plasticity in association with the interaction of oA $\beta_{42}$ with cellular prion protein [6,7], oA $\beta_{42}$ may further induce microglial cell polarization into M1 phenotype along with severe phagocytic function attenuation toward toxic species [8,9]. Moreover, the neuroinflammation 
induced by pro-inflammatory cytokines released from M1 type microglial cells further enhances the apoptosis of neuronal cells [10-12]. By contrast, the M2 phenotype microglial cells exhibit a superior phagocytic capability to eliminate $\mathrm{A} \beta_{42}$ in comparison with other resident central nervous system (CNS) immune cells such as M1 type microglial cells, astrocytes, and possibly neuronal cells [13-15]. Furthermore, the secretion of neurotrophic factors and anti-inflammatory cytokines from M2 microglial cells in brain regions helps repair CNS damage and alleviate inflammation [16]. Unfortunately, naive microglial cells localized in neuroinflammatory regions are apt to differentiate into the M1 phenotype, which further deteriorates inflammatory conditions [17,18].

It has been reported that sulindac sulfide and orcein-related drug $(\mathrm{O})$ can be employed as stimulators for accelerating the aggregation of $\mathrm{oA} \beta_{42}$, which reduce its neurotoxicity for effective $\mathrm{AD}$ treatment $[19,20]$. On the other hand, $\beta$-secretase 1 (BACE) inhibitor was found capable of reducing soluble form of $A \beta_{42}\left(\mathrm{oA} \beta_{42}\right)$ accompanied by rescue of cognitive dysfunction and memory deficits in a mouse model of AD [21]. Similarly, Meier et al. employed a BACE inhibitor (NB-360) to serve as a scavenger for $A \beta$ reduction in tg-ArcSwe mice [22]. Nevertheless, these approaches are somewhat limited due to the ineffective elimination of $\mathrm{oA} \beta_{42}$.

This work was aimed to develop a novel therapeutic strategy to achieve rapid capture and subsequent removal of $\mathrm{oA} \beta_{42}$ and prevention of neuroinflammation for potential $\mathrm{AD}$ treatment. Distinct from small molecule drugs as aforementioned that require a slow progression process involved in the $\mathrm{oA} \beta_{42}$ aggregation, a MSB-based approach was developed and characterized in relation with the capability to effectively capture $\mathrm{oA} \beta_{42}$ into $\mathrm{mpA} \beta_{42}$ by facile magnetic stirring. The MSBs comprising aligned superparamagnetic iron oxide nanoparticles (SPIONs) coated by silica in rod shape were prepared and characterized with respect to the morphology by scanning electron microscopic (SEM) examination and the stirring effect under rotating magnetic field. The therapeutic effect on neuron cells by rapid capture of $\mathrm{oA} \beta_{42}$ with the aid of MSBs under magnetic stirring into mpA $\beta_{42}$ in terms of cell viability and morphology, neuron-specific protein expression, and $\mathrm{oA} \beta_{42}$-induced neuron membrane damage was extensively examined. A reduction in the uptake of $\mathrm{oA} \beta_{42}$ by microglial cells also leads to a significant decrease in polarization of microglial cells into the M1 type. This will then greatly reduce the level of the pro-inflammatory cytokines. The internalization efficiency of $\mathrm{oA} \beta_{42}$ and mpA $\beta_{42}$ by microglial cells and the effect on cell polarization was thus investigated. The in vivo biocompatibility of the MSB-based therapeutic system with stirring in terms of brain tissue damage from C57BL/6 mice was examined by the immunohistochemistry (IHC) staining. To the best of our knowledge, this is the first study demonstrating the rapid capture of $\mathrm{oA} \beta_{42}$ by MSB under magnetic stirring and its potential for AD treatment. The therapeutic strategy developed herein is illustrated schematically in Figure 1. 


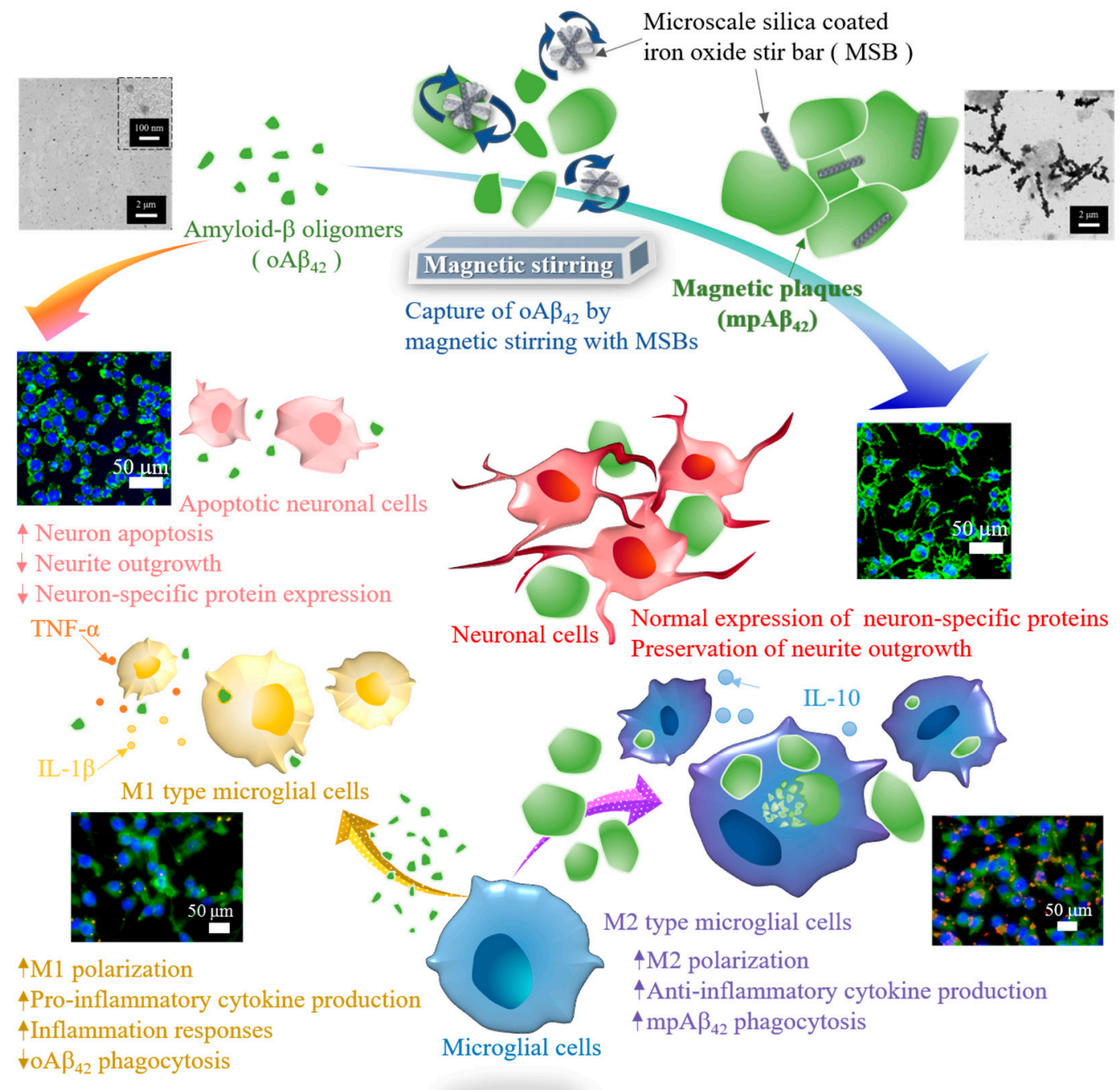

Figure 1. Illustration of the effective therapeutic action by capture of oA $\beta_{42}$ species into magnetic plaques and enhanced cellular clearance by the M2 type microglial cells for AD treatment.

\section{Materials and Methods}

\subsection{Reagents and Materials}

Preparation of oleic acid coated SPIONs (OA-SPIONs) was conducted as reported previously [23]. Congo red (CR), thioflavin $\mathrm{T}(\mathrm{ThT})$, and hematoxylin and eosin (H\&E) were purchased from Sigma-Aldrich (St. Louis, MO, USA). Tetraethyl orthosilicate (TEOS) and 1,1,1,3,3,3-hexafluoro-2propanol (HFIP) were acquired from Alfa Aesar (Haverhill, MA, USA). A $\beta_{42}$ peptide (DAEFRHDSGYEVHHQKLVFFAEDVGSNKGAIIGLMVGGVVIA) was acquired from Chinapeptide (Shanghai, China). Lactate dehydrogenase (LDH) assay kit, Hoechst 33342, rabbit anti-oligomer (A11) polyclonal antibody (AHB0052) and goat anti-mouse IgG secondary antibody (Alexa Fluor 568) were purchased from Thermo Fisher Scientific (Waltham, MA, USA). Anti-mouse F-actin antibody, goat anti-mouse IgG secondary antibody (Alexa Fluor 488), and donkey anti-rabbit IgG secondary antibody (Alexa Fluor 594) were obtained from Abcam (Cambridge, UK). Microtubule-associated protein 2 (MAP2) antibody and anti-human $\beta$-amyloid (6E10) antibody were purchased from BioLegend (San Diego, CA, USA). Neuronal nuclei (NeuN) antibody and neurofilament M (NF-M) antibody were supplied by Merck (Darmstadt, Germany). 4',6-Diamidino-2-phenylindole (DAPI), singlet oxygen sensor green (SOSG) reagent and anti-mouse caspase-3 antibody were purchased by Invitrogen (Eugene, OR, USA). N2a (murine neuroblastoma cells) and BV-2 (murine microglial cells) were obtained from 
Food Industry Research and Development Institute (Hsinchu City, Taiwan). C57BL/6J male mice were purchased from the National Laboratory Animal Center, Taiwan. Approved guidelines for the care and use of laboratory animals by the Institutional Animal Care and Use Committee (IACUC: 10129) were followed.

\subsection{Preparation and Characterization of $M S B S$}

The lauric acid/oleic acid coated SPIONs (LA/OA-SPIONs) were prepared using the oil-in-water emulsion technique. LA sodium salt (200 mg in $15 \mathrm{~mL}$ deionized water) and OA-SPIONs (15 mg in $200 \mu \mathrm{L}$ chloroform) were mixed by ultrasonication for $10 \mathrm{~min}$ in an ice-water bath. This was followed by removal of chloroform by rotary evaporation. The resultant LA/OA-SPIONs were well dispersed in deionized water and phosphate buffered saline (PBS). The mean hydrodynamic diameters $\left(\mathrm{D}_{\mathrm{h}}\right)$, size distributions (polydispersity index, PDI), and zeta potentials of OA- and LA/OA-SPIONs in n-hexane and PBS, respectively, were determined by dynamic light scattering (DLS, ZetaSizer Nano Series, Malvern, UK). Preparation of MSBs was carried out according to the method previously reported [24]. The MSBs in microscale were prepared according to the method reported previously by neodymium magnet assisted alignment of SPIONs into rod-shaped structure in aqueous phase while the SPION surfaces were concomitantly coated with TEOS-based silica to maintain the desired particle morphology and improve the colloidal stability. In brief, LA/OA-SPIONs $(0.05 \mathrm{mg})$ were dispersed in a mixture of isopropanol $(1 \mathrm{~mL})$ and deionized water $(600 \mu \mathrm{L})$ under sonication. $\mathrm{A} \mathrm{NH}_{4} \mathrm{OH}$ solution $(28 \%, 20 \mu \mathrm{L})$ and TEOS $(20 \mu \mathrm{L})$ was added in sequence into the aqueous suspension of LA/OA-SPIONs and the reaction solution was then placed between two $10 \times 20 \times 30 \mathrm{~mm}$ neodymium magnets (4100 gauss) at a distance of $1.0 \mathrm{~cm}$ for $20 \mathrm{~min}$ at room temperature. After removal from the magnetic field, the sample was purified through centrifugation $(1,900 \mathrm{~g}, 2 \mathrm{~min}$ ) with deionized water three times and re-dispersed in deionized water. The morphology of SPIONs and MSBs was examined by transmission electron microscope (TEM) (T7700, Hitachi, Tokyo, Japan). SEM examination was conducted on a Hitachi S-4700 field emission microscope. Characterization of superparamagnetic properties was carried out on a superconducting quantum interference device (SQUID) magnetometer at $300 \mathrm{~K}$ (MPMS-XL Quantum Design, San Diego, CA, USA). The Fe content of OA-SPIONs was determined by thermogravimetric analyzer (TGA, Mettler-Toledo, Greifensee, Switzerland) at a heating rate of $10{ }^{\circ} \mathrm{C} \mathrm{min}^{-1}$. X-ray diffraction (XRD) measurements of OA-SPIONs and LA/OA-SPIONs were conducted on a TTRax III diffractometer (Rigaku, Japan).

\subsection{Preparation and Characterization of $o A \beta_{42}$ and Natural $A \beta_{42}$ Plaques $\left(n p A \beta_{42}\right)$}

$\mathrm{oA} \beta_{42}$ and $\mathrm{npA} \beta_{42}$ were prepared and characterized according to the methods described previously [25-28]. The $\mathrm{A} \beta_{42}$ peptide was initially dissolved in HFIP $(1.0 \mathrm{mM})$ and the solution was divided into aliquotes in sterile microcentrifuge tubes. HFIP was then removed under vacuum. The peptide film thus obtained was stored in dessicator at $-20{ }^{\circ} \mathrm{C}$ before use. The $\beta$-sheet motif of npA $\beta_{42}$ was examined by ThT assay and CR spectroscopic analysis. For ThT assay, A $\beta_{42}$ in dimethyl sulphoxide (DMSO) was added with $100 \mu \mathrm{L}$ PBS (pH 7.4, ionic strength $0.15 \mathrm{M}$ ) to a concentration of $20 \mu \mathrm{M}$ in 96 -well plates. ThT was added $(10 \mu \mathrm{M})$ and the solution was incubated at $37^{\circ} \mathrm{C}$ as a function of time. The fluorescence intensity of ThT was determined by a microplate reader (Infinite M200 PRO, Männedorf, Switzerland). The excitation was performed at $442 \mathrm{~nm}$ and the emission spectrum was recorded in the range of $445-482 \mathrm{~nm}$. The characteristic absorbance of CR at $490 \mathrm{~nm}$ and the red shift in the CR absorption band with the occurrence of $n p A \beta_{42}$ in the range of 490-540 nm was determined using a UV-vis spectrophotometer. For the $100 \mu \mathrm{M}$ oA $\beta_{42}$ preparation, the $\mathrm{A} \beta_{42}$ peptide film was first dissolved in dry DMSO to a concentration of $5 \mathrm{mM}$. The solution was then diluted with the Dulbecco's Modified Eagle's Medium (DMEM) (phenol red-free) to an A $\beta_{42}$ concentration of $100 \mu \mathrm{M}$. The solution was further incubated at $4{ }^{\circ} \mathrm{C}$ for $24 \mathrm{~h}$. The morphology of oA $\beta_{42}$ and npA $\beta_{42}$ was examined by transmission electron microscopy (TEM, HT7700, Hitachi, Tokyo, Japan). Briefly, the A $\beta$ dispersion was dropped onto a carbon-coated copper grid (200 mesh copper grids, Ted Pella, Inc., Redding, CA, 
USA) and stained with $1 \mathrm{wt} \%$ uranyl acetate solution for $1 \mathrm{~min}$ and dried at $25{ }^{\circ} \mathrm{C}$ for 2 days before measurements. The stained samples were analyzed by TEM operating at an accelerating voltage of $100 \mathrm{kV}$.

\subsection{In Vitro Stirring-Induced $o A \beta_{42}$ Capture}

The capture effect of the magnetic stirring treatment with MSBs on $\mathrm{oA} \beta_{42}$ species of varying concentrations $(0.3-160 \mu \mathrm{M})$ under rotating magnetic field at $2500 \mathrm{rpm}$ was determined by fluorescence microscope (Olympus IX70, Tokyo, Japan). Rotating magnetic stirring was conducted on an IKA magnetic stirrer (color squid, Staufen, Germany) with a dynamic magnetic attraction force in the range 15-30 $\mathrm{mT}$. The stirring speed was calibrated with an external speed sensor, which reacts to magnetic impulses. The power consumption is $3 \mathrm{~W}$ and the motor rating output is $2 \mathrm{~W}$. For the preparation of $20 \mu \mathrm{M} \mathrm{oA} \beta_{42}$, the peptide film prepared previously was dissolved in dry DMSO to a concentration of $5 \mathrm{mM}$. The solution was then diluted with the DMEM medium (phenol red-free) to an $\mathrm{A} \beta_{42}$ concentration of $20 \mu \mathrm{M}$, followed by re-incubation at $4{ }^{\circ} \mathrm{C}$ for $24 \mathrm{~h}$. The oA $\beta_{42}(20 \mu \mathrm{M})$ was first treated with magnetic stirring as a function of the concentration of MSBs at $2500 \mathrm{rpm}$ for $20 \mathrm{~min}$. The $\mathrm{A} \beta_{42}$ was then stained with $10 \mu \mathrm{M}$ ThT $(\lambda \mathrm{ex}=442 \mathrm{~nm}, \lambda \mathrm{em}=445-482 \mathrm{~nm})$ and CR $(\lambda e x=497 \mathrm{~nm}$, $\lambda \mathrm{em}=596-632 \mathrm{~nm}$ ) dyes. The total and mean areas of the stained $\mathrm{mpA} \beta_{42}$ were quantified with the functions of Image-Pro Plus $6.0(n=10)$. The morphology of $\mathrm{mpA} \beta_{42}$ was examined by TEM, scanning probe microscopy (SPM, tapping mode, Bruker, Model-Dimension Icon, Camarillo, CA, USA) and atomic force microscope (AFM, Bruker, Santa Barbara, CA, USA) [29-32].

\subsection{Cell Membrane Damage and Neurite Outgrowth Impairment}

3-(4,5-Dimethylthiazol-2-yl)-2,5-diphenyltetrazolium bromide (MTT) and trypan blue assays were used to determine the cell viability of N2a cells co-incubated with oA $\beta_{42}$ species $(160 \mu \mathrm{M})$ under the MSB stirring treatment ( $2500 \mathrm{rpm}, 2 \mathrm{~h}$ ). For $160 \mu \mathrm{M}$ oA $\beta_{42}$ preparation, the peptide film obtained previously was dissolved in dry DMSO to a concentration of $5 \mathrm{mM}$. The solution was then diluted with the DMEM medium (phenol red-free) to an $\mathrm{A} \beta_{42}$ concentration of $160 \mu \mathrm{M}$, followed by re-incubation at $4{ }^{\circ} \mathrm{C}$ for $24 \mathrm{~h}$. N2a cells were first seeded into 96 -well plates at a concentration of $5 \times 10^{3} \mathrm{cells} /$ well in $200 \mu \mathrm{L}$ DMEM, containing $10 \%$ fetal bovine serum (FBS) and $1 \%$ penicillin, and incubated at $37^{\circ} \mathrm{C}$ overnight in an atmosphere of $5 \% \mathrm{CO}_{2}$. N2a cells were then co-incubated with oA $\beta_{42}(160 \mu \mathrm{M})$ with or without MSB-based $\left(144 \mu \mathrm{g} \mathrm{mL}^{-1}\right)$ stirring at $2500 \mathrm{rpm}$ for another $2 \mathrm{~h}$. After being washed twice with PBS, cells were re-incubated in DMEM for another $24 \mathrm{~h}$. MTT $(0.25 \mu \mathrm{g} / \mathrm{mL})$ in DMEM $(200 \mu \mathrm{L})$ was added into each well, followed by re-incubation at $37^{\circ} \mathrm{C}$ for $4 \mathrm{~h}$. The culture medium was then replaced with DMSO $(100 \mu \mathrm{L})$ and the absorbance of each well at $570 \mathrm{~nm}$ was determined by the microplate reader. The MTT assay for the cell viability evaluation was performed based upon the measurement of the cellular metabolic activity, in particular with respect to the activity of mitochondria reductase (dehydrogenase) by colorimetric determination. Trypan blue assay was used to determine the number of viable N2a cells. In brief, trypan blue solution $(0.4 \%)$ in DMEM $(200 \mu \mathrm{L})$ was co-incubated with N2a cells being treated with either oA $\beta_{42}(160 \mu \mathrm{M})$ alone or oA $\beta_{42} /$ magnetic stirring $(2500 \mathrm{rpm}, 2 \mathrm{~h})$ for $24 \mathrm{~h}$ at $37^{\circ} \mathrm{C}$. The viable N2a cells with intact cell membranes that prevent trypan blue from permeation into cells was then examined by optical microscopy. The effects of $\mathrm{oA} \beta_{42}$ and $\mathrm{mpA} \beta_{42}$ on neuron apoptosis in terms of the level of cell membrane damage was evaluated by measuring the release of LDH, a cytosolic enzyme from the damage cells [33]. The neurite outgrowth was examined by laser scanning confocal microscope (LSCM, ZEISS LSM-780, Jena, Germany). The cell nuclei and cytoskeletons were stained with Hoechst 33342 and CytoPainter F-actin Staining Kit-Green Fluorescence, respectively. Mean number and length $(\mu \mathrm{m})$ of neurites were calculated by Neurolucida software (Version 8 , MBF Bioscience, USA), respectively. The mean neurite length was defined herein as the ratio of the sum of neurite length to the number of neurite. At least three independent experiments were performed in this study, and at least 50 cells quantified per experiment. 


\subsection{Cell Functions}

The cellular functions in terms of specific protein expression were examined by western blotting. Proteins were subjected to a $12 \%$ sodium dodecyl sulfate-polyacrylamide gel electrophoresis (SDS-PAGE) and transferred onto polyvinylidene difluoride (PVDF) membrane. The PVDF membrane was blocked using 5\% nonfat milk blocking buffer with anti-MAP-2, NF-M, and NeuN primary antibody at $4{ }^{\circ} \mathrm{C}$ for $24 \mathrm{~h}$. It was then incubated at $37^{\circ} \mathrm{C}$ for $1 \mathrm{~h}$ with horseradish peroxidase-conjugated secondary antibody. $\beta$-Actin was used as the loading control. The area and signal intensity of the detected bands were determined using the Molecular Imager PharosFX Plus System and quantified using the ImageJ software (v1.33, National Institute of Mental Health, MD, USA). For the LSCM examination, N2a cells on glass coverslips were treated with MSBs $(144 \mu \mathrm{g})$, free oA $\beta_{42}(160 \mu \mathrm{M})$, and oA $\beta_{42} / \mathrm{MSBs}$, respectively, either with or without $2 \mathrm{~h}$ magnetic stirring $(2500 \mathrm{rpm})$ at $37{ }^{\circ} \mathrm{C}$. With additional $22 \mathrm{~h}$ incubation, the cells were washed with PBS three times and fixed with $4 \%$ formaldehyde. Triton X-100 (0.1\%) was added to increase the cell permeability. After being rinsed with PBS, the cells were then co-incubated in sequence with mouse anti-mouse MAP-2 antibody as the primary antibody and goat anti-mouse Alexa Fluor 488 as the secondary antibody at ambient temperature. Cells were further IHC stained for NF-M similarly while the rabbit anti mouse NF-M and donkey anti-rabbit antibodies (conjugated with Alexa Fluor 594) as primary and secondary antibody was employed for NF-M detection. Finally, cells were stained with Hoechst $33342\left(5 \mu \mathrm{g} \mathrm{mL}^{-1}\right)$ to identify cell nuclei.

\subsection{Phagocytic Activity of Microglial Cells}

BV-2 cells were adopted as a microglia cell model for evaluating the uptake of $A \beta_{42}$ in different forms (i.e., oA $\beta_{42}, \mathrm{npA} \beta_{42}$ and $\left.\mathrm{mpA} \beta_{42}\right)$. BV-2 cells $\left(3 \times 10^{5}\right.$ cells per well) were seeded on glass coverslips and cultured at $37^{\circ} \mathrm{C}$ under $5 \% \mathrm{CO}_{2} /$ air overnight. This was followed by co-incubation with the $A \beta_{42}$ species at varying concentrations. With $6 \mathrm{~h}$ co-incubation, the coverslips were washed with PBS twice, fixed with $4 \%$ paraformaldehyde and stained with 6 E10 for $10 \mathrm{~min}$ in sequence. The extent of cellular uptake of $A \beta_{42}$ in different forms by microglia was visualized at the excitation and emission wavelengths of $488 \mathrm{~nm}$ and $590 \mathrm{~nm}$, respectively, with LSCM.

\subsection{Cytokine Production}

Levels of IL-1 $\beta$, TNF- $\alpha$ and IL-10 released from BV-2 cells after uptake of $A \beta_{42}$ species of various structures were examined by enzyme-linked immunosorbent assay (ELISA). A 96-well tailor-made mouse multi-analyte ELISArray kit (Qiagen, SA Biosciences, Hilden, UK) was employed to determine the concentrations of TNF- $\alpha$, IL- $1 \beta$, and IL-10 in the collected culture media according to the manufacturer's instruction.

\subsection{Brain Tissue Toxicity and Damage with MSB Stirring}

The intracranial injection of $2 \mu \mathrm{L}$ of the aqueous MSB dispersion $(0.5$ and $1.0 \mu \mathrm{g}$ in $2 \mathrm{~mL}$ of F-12K medium, respectively) into the hippocampus area of healthy C57BL/6J mice with the magnetic stirring was conducted in this work to evaluate the in vivo brain tissue toxicity and damage by MSB stirring [34-36]. In brief, male C57BL/6J mice (6-8 weeks old) were first anesthetized with Zoletil-Rompun by intraperitoneal injection and placed in an animal stereotaxic apparatus (Stoelting, Wood Dale, IL, USA). Two $\mu \mathrm{L}$ of the aqueous MSB dispersion were injected intracranially into the hippocampus area using a $10 \mu \mathrm{L}$ Hamilton syringe equipped on the stereotaxic instrument with a 27-gauge needle and a microinjection auto-pump (KD Scientific, Hollison, MA, USA). After the needle was gently withdrawn, the burr hole was immediately sealed with bone wax and the surgical incision was sutured. This was followed by magnetic stirring ( $2400 \mathrm{rpm})$ over $20 \mathrm{~min}$. At the prescribed time points, the brains were isolated and sectioned. The reactive oxygen species (ROS) level induced from $\mathrm{Fe}^{2+}$ and $\mathrm{Fe}^{3+}$ ions (Fenton reaction) with the dissolution of MSBs was determined by SOSG. The cell 
apoptosis in brain tissue sections was examined by caspase 3 IHC staining. The Prussian blue staining was used to determine the Fe content in brain tissue with time. The hippocampus tissue sections were H\&E stained for histologic examination under optical microscopy.

\subsection{Statistical Analysis}

All experiments were performed at least in triplicate and data were reported as mean \pm standard deviation. Statistical significance was determined using one-way ANOVA and Bonferroni post-hoc test. Significant differences were defined as $\left(^{*}\right) p<0.05,\left({ }^{* *}\right) p<0.01$, and $\left({ }^{* * *}\right) p<0.005$. Not significant differences were displayed as N.S. $(p>0.05)$.

\section{Results and Discussion}

\subsection{Preparation and Characterization of MSBs}

The MSBs in microscale were prepared according to the method reported previously [24]. Through the neodymium magnet assisted alignment of SPIONs into rod-shaped structure in aqueous phase, the SPION surfaces were concomitantly coated with TEOS-based silica to maintain the desired particle morphology and improve the colloidal stability. The particle surface of SPIONs in the form of OA-SPIONs prepared by the thermal decomposition technique were modified with LA by hydrophobic association to improve the aqueous colloidal dispersion. The results obtained from characterization of OA-SPIONs and LA/OA-SPIONs by TEM, TGA, SQUID, and XRD are shown in Figure S1. TEM images of LA/OA-SPIONs and OA-SPIONs confirm their spherical particle morphology. The resultant LA/OA-SPIONs still retain excellent superparamagnetic behavior with similar hysteresis to OA-SPIONs (Figure S1d). In addition, the XRD patterns of OA-SPIONs and LA/OA-SPIONs show high crystallinity in the spherical phase structure of $\mathrm{Fe}_{3} \mathrm{O}_{4}$ (JCPDS: 65-3107) (Figure S1e). Table S1 also shows the mean hydrodynamic diameters of OA-SPIONs in n-hexane and LA/OA-SPIONs in PBS and the zeta potential of LA/OA-SPIONs at pH 7.4. The optical microscopic, SEM, TEM, and high resolution TEM (HR-TEM) images of the MSBs developed herein are shown in Figure 2. The dimensions of MSBs were ca. $2.9 \pm 0.7 \mu \mathrm{m}$ in length and $132.4 \pm 4.1 \mathrm{~nm}$ in diameter with the thickness of silica coating at ca. $45.5 \pm 5.2 \mathrm{~nm}$ estimated by TEM image. The HR-TEM image further confirms the confinement of LA/OA-SPIONs in a relatively linear architecture within the silica coat (Figure $2 \mathrm{~d}$ ).

In the absence of magnetic field, MSBs remained as rod-like particles randomly dispersed in the continuous aqueous phase, as illustrated in Figure S2a. By contrast, MSBs became uniformly aligned in response to the direction of the applied external magnetic field (Figure S2b). The stirring effect of MSBs was observed by the accelerated dispersion of rhodamine B employed as a fluorescence dye in a water droplet in the presence of MSBs under an external magnetic rotating field (Figure S2c). Without magnetic stirring, the dye species resided locally within the water droplet. On the contrary, the dye species subjected to magnetic stirring became rapidly dispersed in the droplet and the extent of dispersion was dependent on the stirring speed and duration. Notably, a homogenous aqueous solution of rhodamine B was achieved over $20 \mathrm{~s}$ of stirring at $2500 \mathrm{rpm}$. The rapid rotation of MSBs is illustrated in Video S1, in which individual rotations of MSBs at various stirring speeds were recorded. The blinking phenomenon caused by light scattering during magnetic stirring was also observed (Video S2), similar to what has been reported elsewhere [37]. The colloidal stability of MSBs in different aqueous milieus was also evaluated in terms of the time-evolved change of light scattering intensity by DLS measurements. Figure S3 illustrates negligible variations in count rate of the aqueous MSB dispersions over a period of $1 \mathrm{~h}$, indicating excellent colloidal stability under 500; 1500; or $2500 \mathrm{rpm}$ magnetic stirring. Similar observation from the silica-coated nanoparticles was reported in the literature [38]. Being quite similar in surface modification, silica coating exhibited a strong resistance against both salt-induced aggregation in PBS and protein adsorption-evolved coagulation in Dulbecco's modified Eagle medium (DMEM) solution primarily because of the high negative surface charge density of MSBs ( $\zeta$-potential of ca. $-35 \mathrm{mV})$. 
a
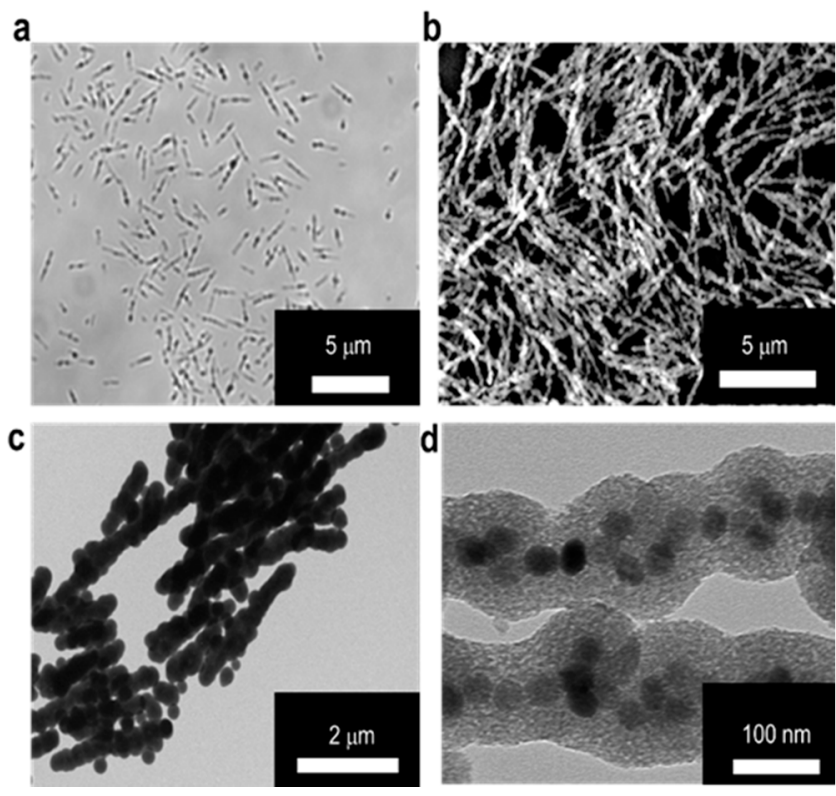

Figure 2. Characterization of microscale silica-coated iron oxide stir bars (MSBs). Morphology of MSBs examined by (a) optical microscope in aqueous solution and (b) SEM in dry state. (c) TEM image of MSBs. Scale bar: $2 \mu \mathrm{m}$. (d) HR-TEM image of MSBs. Scale bar: $100 \mathrm{~nm}$.

\subsection{Capture Efficiency of $A \beta_{42}$ by Magnetic Stirring of MSBs and In Vitro Therapeutic Efficacy}

Rapid agglutination and capture of oA $\beta_{42}$ into $m p A \beta_{42}$ in cell culture medium by means of magnetic stirring with MSBs was studied first by fluorescence microscopy. As shown by the fluorescence images in Figure 3, the signal areas of both ThT and CR in the aqueous oA $\beta_{42}$ solution subjected to magnetic stirring treatment increase dramatically compared to those without magnetic stirring treatment. These signals were observed obviously owing to the formation of $\mathrm{oA} \beta_{42}$ aggregates. The total areas detected are in the range $2 \times 10^{5} \sim 3 \times 10^{5} \mu \mathrm{m}^{2}$ while the mean areas in the range $110-130 \mu \mathrm{m}^{2}$ with oA $\beta_{42}$ being treated with magnetic stirring (Figure 3). The signal areas from ThT and CR overlapped mostly, indicating that both staining occurred at the same places. At constant stirring speed ( $2500 \mathrm{rpm})$, a rather weak dependence of the total signal area of the ThT/CR stained $A \beta_{42}$ aggregates on the concentration of MSB in the range $144-576 \mu \mathrm{g} / \mathrm{mL}$ employed herein was observed. The effect of the MSB concentration $\left(144-576 \mu \mathrm{g} / \mathrm{mL}\right.$ ) on the mean signal area (i.e., the $\mathrm{oA} \beta_{42}$ aggregate size) is also essentially insignificant. In contrast to the magnetic stirring effect, the fluorescence signals of both ThT and CR were barely detected from the aqueous solution of $\mathrm{oA} \beta_{42}$ without stirring over a period of $20 \mathrm{~min}$. This result strongly suggests that the $\mathrm{oA} \beta_{42}$ aggregate formation is substantially promoted by the magnetic stirring provided by MSBs as compared to the counterpart that is not subjected to stirring. It is noteworthy that the sound capture of $\mathrm{oA} \beta_{42}$ is successfully achieved by magnetic stirring even at a concentration of $0.3 \mu \mathrm{M}$. This implies the potential of the magnetic stirring with MSBs in practical applications for AD treatment (Figure S4).

The capture of $o A \beta_{42}$ into $m p A \beta_{42}$ via magnetic stirring with MSBs was further supported by comparison of the $\mathrm{oA} \beta_{42}$ images before and after the magnetic stirring treatment using the TEM and AFM techniques (Figure 4). The TEM images clearly demonstrate the agglutination of oA $\beta_{42}$ after the magnetic stirring with MSBs while the small oA $\beta_{42}$ species were well separated from MSBs in the absence of the magnetic stirring treatment (Figure 4a). Both the 2-D and 3-D AFM topographic maps also corroborate the $\mathrm{oA} \beta_{42}$ plaque formation promoted by MSB stirring with the plaque size being enormously enlarged in comparison with the oligomers (Figure $4 b$ ). 


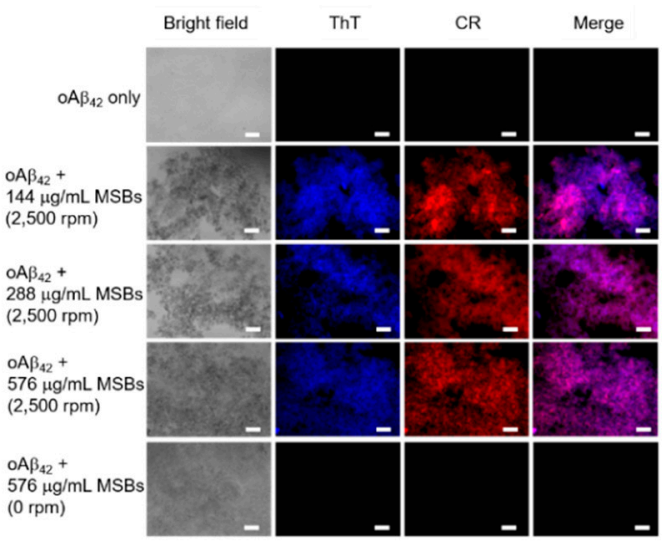

(a)

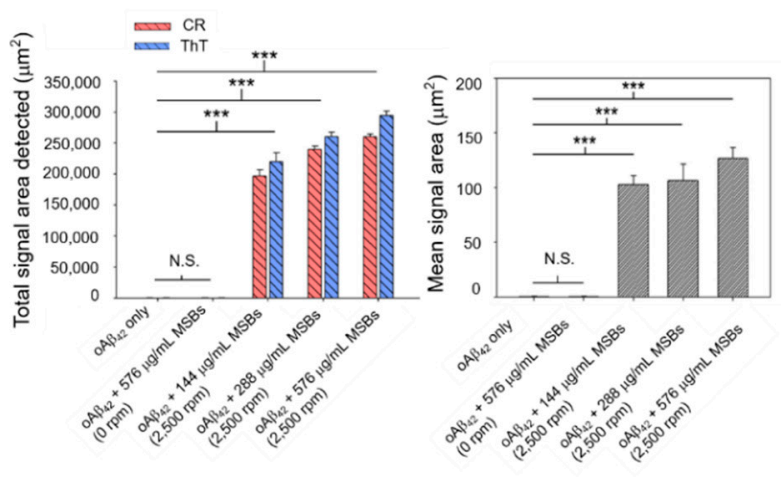

(b)

Figure 3. Capture of $\mathrm{oA} \beta_{42}$ into $\mathrm{mpA} \beta_{42}$ by magnetic stirring with MSBs. (a) Fluorescence images of $\mathrm{oA} \beta_{42}(20 \mu \mathrm{M})$ treated with magnetic stirring as a function of the concentration of MSBs at $2500 \mathrm{rpm}$ for $20 \mathrm{~min}(n=10)$. Scale bar: $100 \mu \mathrm{m}$. (b) The total and mean signal areas detected from the A $\beta_{42}$ aggregation induced by magnetic stirring with MSBs were included. ${ }^{* * *} p<0.005$ and N.S. $p>0.05$. Error bars represent mean \pm s.d. $(n=10)$.

a $\quad \mathrm{OA} \beta_{42}$

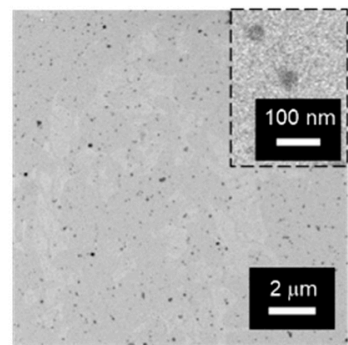

b
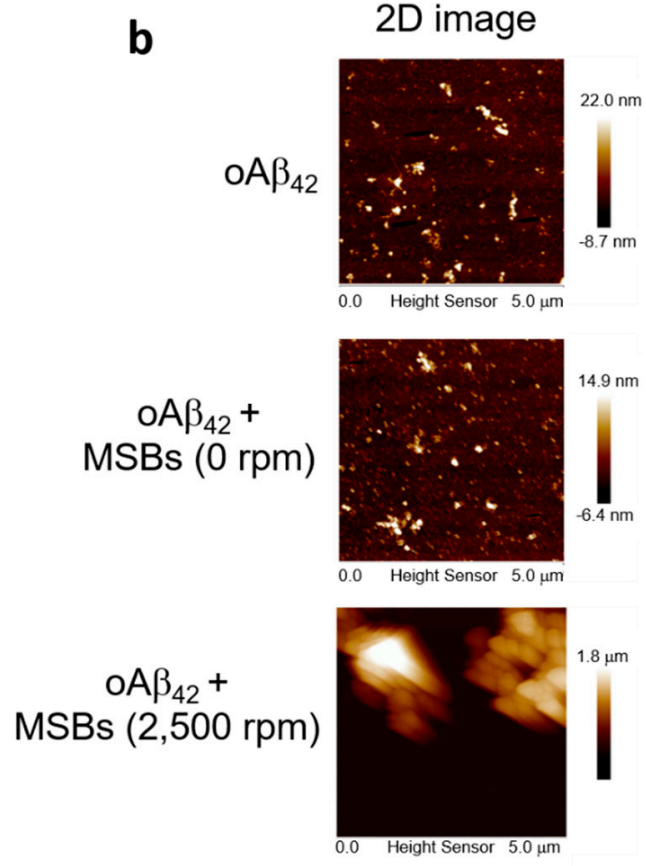
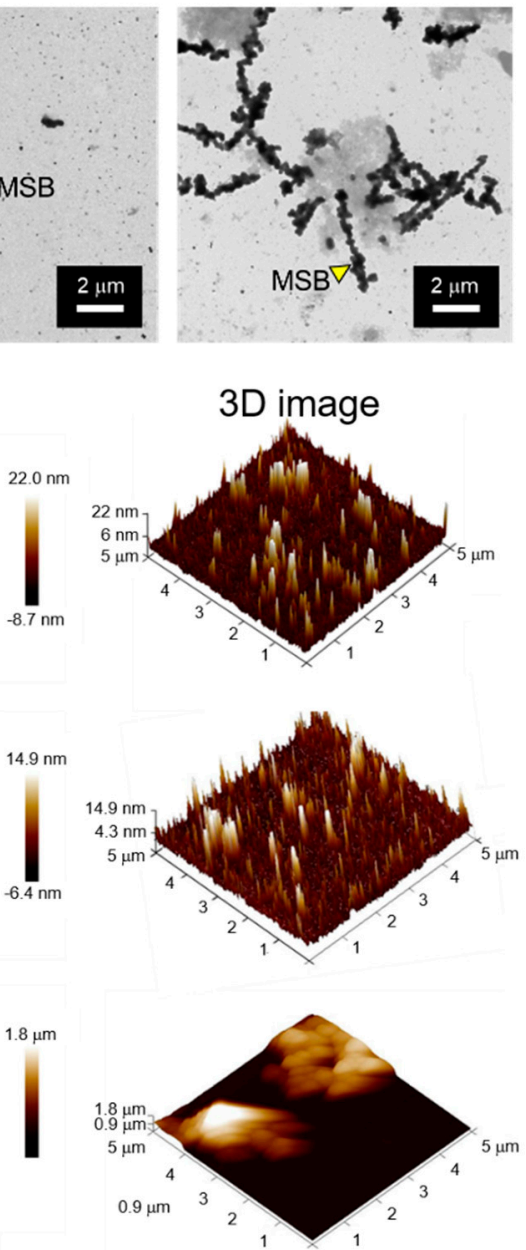

$\mathrm{OA} \beta_{42}+\operatorname{MSBs}(2,500 \mathrm{rpm})$

Figure 4. Structural analyses of $\mathrm{oA} \beta_{42}$ and $\mathrm{mpA} \beta_{42}$ by TEM and AFM. (a) TEM images of effective capture of $\mathrm{oA} \beta_{42}$ into $\mathrm{mpA} \beta_{42}$ via magnetic stirring. Scale bar: $2 \mu \mathrm{m}$. (b) Examination of mpA $\beta_{42}$ by AFM. 2D topographic images of $\mathrm{oA} \beta_{42}, \mathrm{oA} \beta_{42}+$ MSBs $(0 \mathrm{rpm})$, and oA $\beta_{42}+$ MSBs (2500 rpm); and 3D topographic representations of $\mathrm{oA} \beta_{42}, \mathrm{oA} \beta_{42}+\operatorname{MSBs}(0 \mathrm{rpm})$, and oA $\beta_{42}+\mathrm{MSBs}$ (2500 rpm). 
Figure S5a shows that the fluorescence intensity of ThT in the aqueous oA $\beta_{42}$ solution increases significantly as the time-evolved $n \mathrm{pA} \beta_{42}$ form although over a relatively prolonged period of time (5-7 days) is required. The increase of the fluorescence intensity is ascribed to the restriction of the rotation of both benzylamine and benzathiole rings of ThT once the dye binds with $A \beta_{42}$ in the forms of both fibrils and naturally occurring plaques which are enriched with the $\beta$-sheet structure [39-42]. Similar to the data reported elsewhere $[43,44]$, a red shift in the wavelength of the maximum absorbance of CR from 490 to $540 \mathrm{~nm}$ was observed upon the association of CR with the insoluble $\beta$-sheet rich $\mathrm{A} \beta_{42}$ aggregates such as fibrils and $n p A \beta_{42}$ (Figure S5b). Figure S5c,d show the TEM images of oA $\beta_{42}$ and npA $\beta_{42}$, respectively. The latter was obtained from the incubation of oA $\beta_{42}$ in $\mathrm{PBS}$ at $37^{\circ} \mathrm{C}$ under mild shaking over 7 days. TEM images show that $n p A \beta_{42}$ fully comprises fibrils while the aggregate size (ca. $70 \mu \mathrm{m}^{2}$ attained from the fluorescence microscopic examination) is somewhat smaller than that of $\operatorname{mpA} \beta_{42}$ (ca. $125 \mu \mathrm{m}^{2}$ ). It is interesting to note that the ThT fluorescence intensity reaches a plateau value of ca. 35,000 (a.u.) for the $n p A \beta_{42}$ formation compared to ca. 20,000 for ThT with $\operatorname{mpA} \beta_{42}$ at the same concentration of $\mathrm{A} \beta_{42}(20 \mu \mathrm{M})$ and ca. 1000 for ThT alone in aqueous solution. Comparing the structures of $n p A \beta_{42}$ and oA $\beta_{42}$ shown by TEM images, obviously oA $\beta_{42}$ species are rather void of the fibril structure (Figure S5c), which by contrast predominates in npA $\beta_{42}$ (Figure S5d). With $\mathrm{mpA}_{42}$ being formed via the rapid capture of $\mathrm{oA} \beta_{42}$ with the MSB stirring treatment, a decrease in the fluorescence intensity of ThT when bound with $\mathrm{mpA} \beta_{42}$ in comparison with the signal intensity associated with the $n p A \beta_{42}$ formation can thus be expected. Since the size of $n p A \beta_{42}$ is smaller than that of $\operatorname{mpA} \beta_{42}$, the effect of the magnetic stirring treatment on $n p A \beta_{42}$ was also examined. Figure S6a shows the capability of the MSB stirring to readily capture $n p A \beta_{42}(20 \mu \mathrm{M})$ into larger aggregates at a speed of $2500 \mathrm{rpm}$ over $20 \mathrm{~min}$. The extent of aggregation in terms of the detected total signal area closely correlating to the concentration of MSB employed for magnetic stirring was also observed (Figure S6b).

The effects of structural transformation from oA $\beta_{42}$ to $\mathrm{mpA} \beta_{42}$ by magnetic stirring treatment on neuron cells (N2a) was investigated in terms of cell viability, cell morphology, and cell-specific protein expression. First, the in vitro cytotoxicity of $m p A \beta_{42}$ induced by the rapid capture of oA $\beta_{42}$ species against N2a cells was evaluated using MTT and trypan blue assays. In the absence of oA $\beta_{42}, \mathrm{MSBs}$ $\left(144 \mu \mathrm{g} \mathrm{mL}^{-1}\right)$ without or with magnetic stirring at $2500 \mathrm{rpm}$ for $2 \mathrm{~h}$ resulted in negligible cell death as measured by MTT assay (Figure 5a). The cell viability was also barely affected by the stirring speed (0; 500; 1500; and $2500 \mathrm{rpm}$ ) and the concentration of MSB (up to $144 \mu \mathrm{g} \mathrm{mL}^{-1}$ ) employed for the rapid $\mathrm{oA} \beta_{42}$ capture in the culture medium (Figure S7). By contrast, with those cells being exposed to oA $\beta_{42}$ without the stirring treatment, the cell viability was significantly reduced compared to the cell only control. This result is consistent with those reported previously that oA $\beta_{42}$ species are responsible in large measure for neuron toxicity in AD [45-48]. Nevertheless, an essentially full retention of the viability of $\mathrm{N} 2 \mathrm{a}$ cells incubated with oA $\beta_{42}$ was observed when the $\mathrm{N} 2 \mathrm{a} / \mathrm{oA} \beta_{42}$ suspension was concomitantly treated with the MSB stirring. The greatly reduced cytotoxicity is ascribed to the rapid capture of the $\mathrm{oA} \beta_{42}$ into large aggregates by which the $\mathrm{A} \beta_{42}$ structure is appreciably altered and their entry into N2a cells extremely limited. The cytotoxicity of oA $\beta_{42}$ against N2a cells via the MSB stirring treatment was also evaluated by the trypan blue staining as a measure of cell apoptosis. As shown in Figure $5 b$, the cytotoxicity of oA $\beta_{42}$ was appreciably reduced as these toxic species were captured and converted into large magnetic aggregates. Figure $5 \mathrm{c}$ illustrates that the LDH release from N2a cells caused by $\mathrm{oA} \beta_{42}$ is greatly reduced by the magnetic stirring treatment in comparison with the run without the treatment. Apparently, the cytotoxicity of oA $\beta_{42}$ species was considerably alleviated by their magnetic capture into large aggregates, thereby leading to the significant reduction of cellular uptake of oA $\beta_{42}$ by N2a cells for neurotoxicity attenuation. Figure $5 \mathrm{~d}$ demonstrates the comparable neuron-specific protein expression of $\mathrm{N} 2 \mathrm{a}$ cells in the presence of oA $\beta_{42}$ subjected to magnetic stirring to the positive control. In contrast, the neuron specific protein expression was significantly suppressed for the run without the capture of oA $\beta_{42}$ species into large aggregates of oA $\beta_{42} / \mathrm{MSBs}$. Note that the proteins chosen for study include MAP2 and NF-M. Finally, further supporting evidence was provided 
by the neurite morphology. As shown in Figure S8, the morphology of N2a cells, in particular the neurites (axons and dendrites), was well preserved when they were treated by oA $\beta_{42}$ in virtue of the superior capture effect of magnetic stirring. The neurite length of N2a cells (ca. $20 \mu \mathrm{m}$ ) in the magnetic stirring-treated group was well retained as comparable to the positive control without oA $\beta_{42}$. By contrast, the length of neurites was reduced to ca. $3 \mu \mathrm{m}$ with the cells being treated with oA $\beta_{42}$ only. All these results strongly suggest that the MSB stirring treatment is highly capable of capturing toxic oA $\beta_{42}$ species and, consequently, reducing their toxicity against neuronal cells. As a result, rather high cell integrity and viability are achieved.
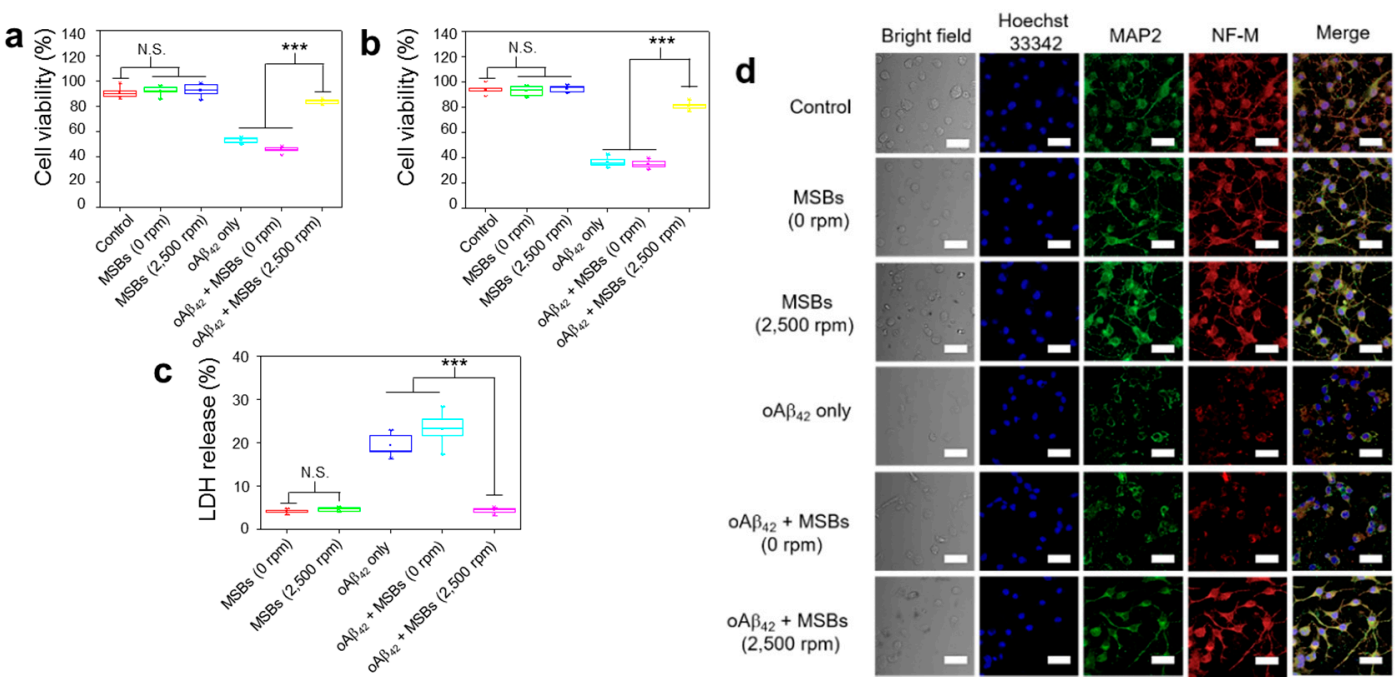

Figure 5. Effective therapeutic action by capture of $\mathrm{oA} \beta_{42}$ under magnetic stirring with MSBs. (a) In vitro cytotoxicity of N2a cells with or without magnetic stirring treatment by MTT and (b) trypan blue assays. The experiment was independently repeated three times. Error bars show standard deviations. (c) LDH release from N2a cells with and without the oA $\beta_{42}$ capture by the MSB stirring treatment. (d) Effects of $\mathrm{oA} \beta_{42}$ on neuron-specific protein expression (MAP2 and NF-M) with and without the magnetic stirring treatment $(n=6)$. Cell nuclei were stained with Hoechst $33342\left(\lambda_{\mathrm{ex}}=405 \mathrm{~nm}, \lambda_{\mathrm{em}}=450-500 \mathrm{~nm}\right)$, microtubules with MAP2 marker $\left(\lambda_{\mathrm{ex}}=495 \mathrm{~nm}, \lambda_{\mathrm{em}}=500-550 \mathrm{~nm}\right)$ and neurofilaments with NF-M marker $\left(\lambda_{\mathrm{ex}}=633 \mathrm{~nm}, \lambda_{\mathrm{em}}=640-660 \mathrm{~nm}\right)$. Scale bar: $50 \mu \mathrm{m}$. ${ }^{* * *} p<0.005$ and N.S. $p>0.05$. Error bars represent mean \pm s.d. $(n=8)$.

\subsection{Functionality of N2a Cells and Phagocytic Action of BV-2 Cells}

The cellular functions in terms of specific protein expression after the rapid oA $\beta_{42}$ capture treatment on neuron cells were examined by western blotting. Figure 6 demonstrates that the MAP2 proteins, the NF-M protein, and NeuN were found normally expressed from N2a cells with a negligible effect of $\mathrm{oA} \beta_{42}$ under magnetic stirring. On the other hand, the specific protein expression was significantly reduced in the negative control by oA $\beta_{42}$ without magnetic stirring. The quantification of the specific protein expression is also shown in Figure 6. Moreover, in the presence of npA $\beta_{42}$ instead of oA $\beta_{42}$, the specific expression of MAP2a, MAP2b, MAP2c, or NF-M on N2a cells was comparable to the blank control. This signifies that the neurotoxicity of both npA $\beta_{42}$ and $m p A \beta_{42}$ against $N 2 a$ cells is substantially reduced compared to oA $\beta_{42}$ (Figure S9). In excellent agreement with the data obtained from the cell viability and morphology (Figure 5 and Figure S8), these results strongly imply that the effective therapeutic action is indeed achieved by capture of oA $\beta_{42}$ via MSBs under rotating magnetic field. 


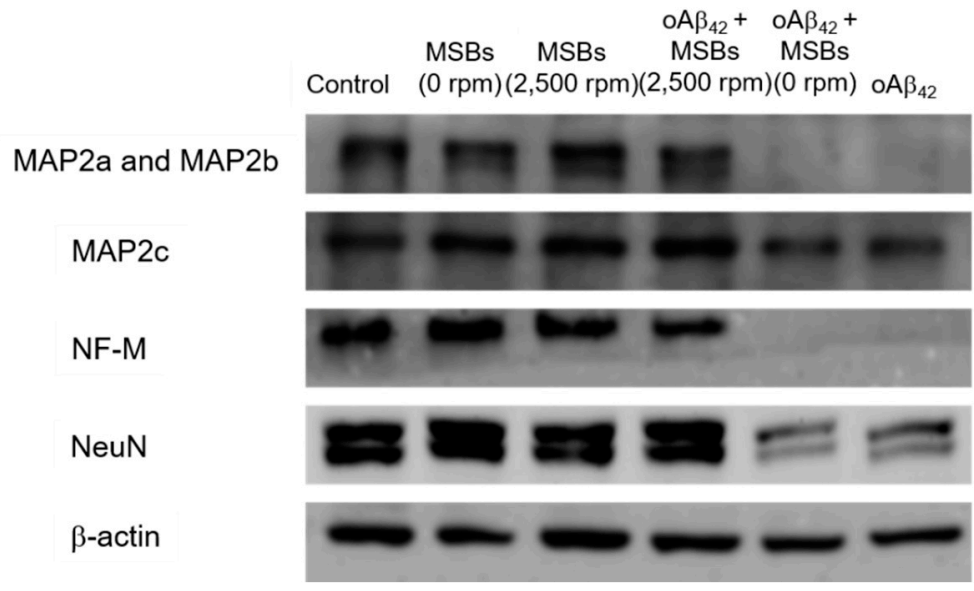

(a)
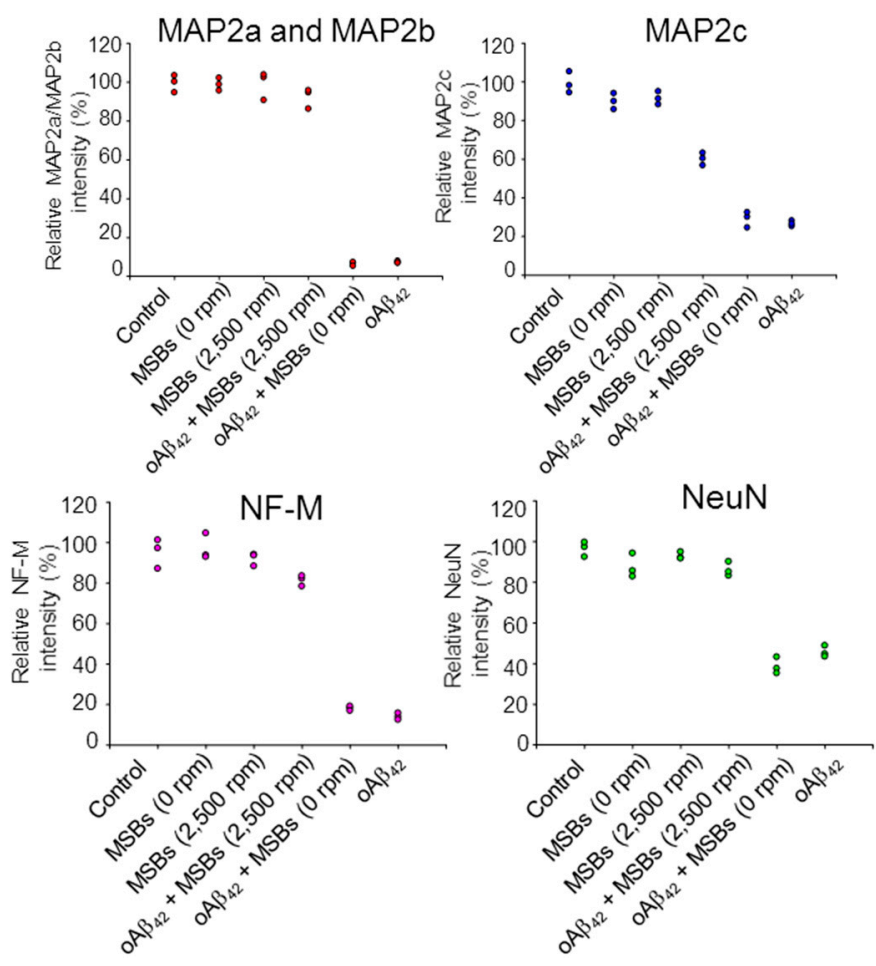

(b)

Figure 6. Neuron-specific protein expression of N2a cells receiving the magnetic stirring treatment. (a) Effects of $\mathrm{oA} \beta_{42}$ on protein expression (MAP2a/MAP2b, MAP2c, NF-M, and NeuN) with and without the magnetic stirring $(n=3)$. $\beta$-actin was used as the loading control. The $\mathrm{oA} \beta_{42}$ concentration was $160 \mu \mathrm{M}$. (b) The relative intensities of neuron-specific protein expression of N2a cells receiving magnetic stirring with MSBs were included.

As illustrated in Figure 7 and Figure S10, BV-2 cells (as a microglial cell model) treated with $\mathrm{oA} \beta_{42}$ species exhibited quite weak fluorescence signals from Triton X-100 facilitated intracellular IHC staining using $6 \mathrm{E} 10$ as the primary antibody. In contrast, the fluorescence signal intensity was greatly enhanced for the cells treated with either $n p A \beta_{42}$ or mpA $\beta_{42}$. This is most likely due to the enhanced uptake of $\mathrm{mpA} \beta_{42}$ (or $n p A \beta_{42}$ ) aggregates with activating the toll-like receptor (TLR)-associated endocytosis [49-52]. It was reported that the interactions of TLR-4 with CD14 on cell membranes were enhanced through the activation of $\mathrm{CD} 14$ upon their binding with $\mathrm{A} \beta_{42}$ species, triggering the TLR/CD14-mediated endocytosis [53]. On the other hand, the enhanced uptake of $\mathrm{mpA} \beta_{42}$ by BV- 2 cells compared to $n p A \beta_{42}$ (Figure 7) is presumably caused by their enlarged size that inevitably increases 
contacts with CD14 on the cell membrane, thereby facilitating the TLR-mediated phagocytosis. It has been recognized that the internalization of $\mathrm{oA} \beta_{42}$ species by microglia induces the M1 phenotype polarization of the cells, known for the reduced phagocytic activity toward neurotoxic species [54]. This will then lead to an increase in neuron apoptosis.

a

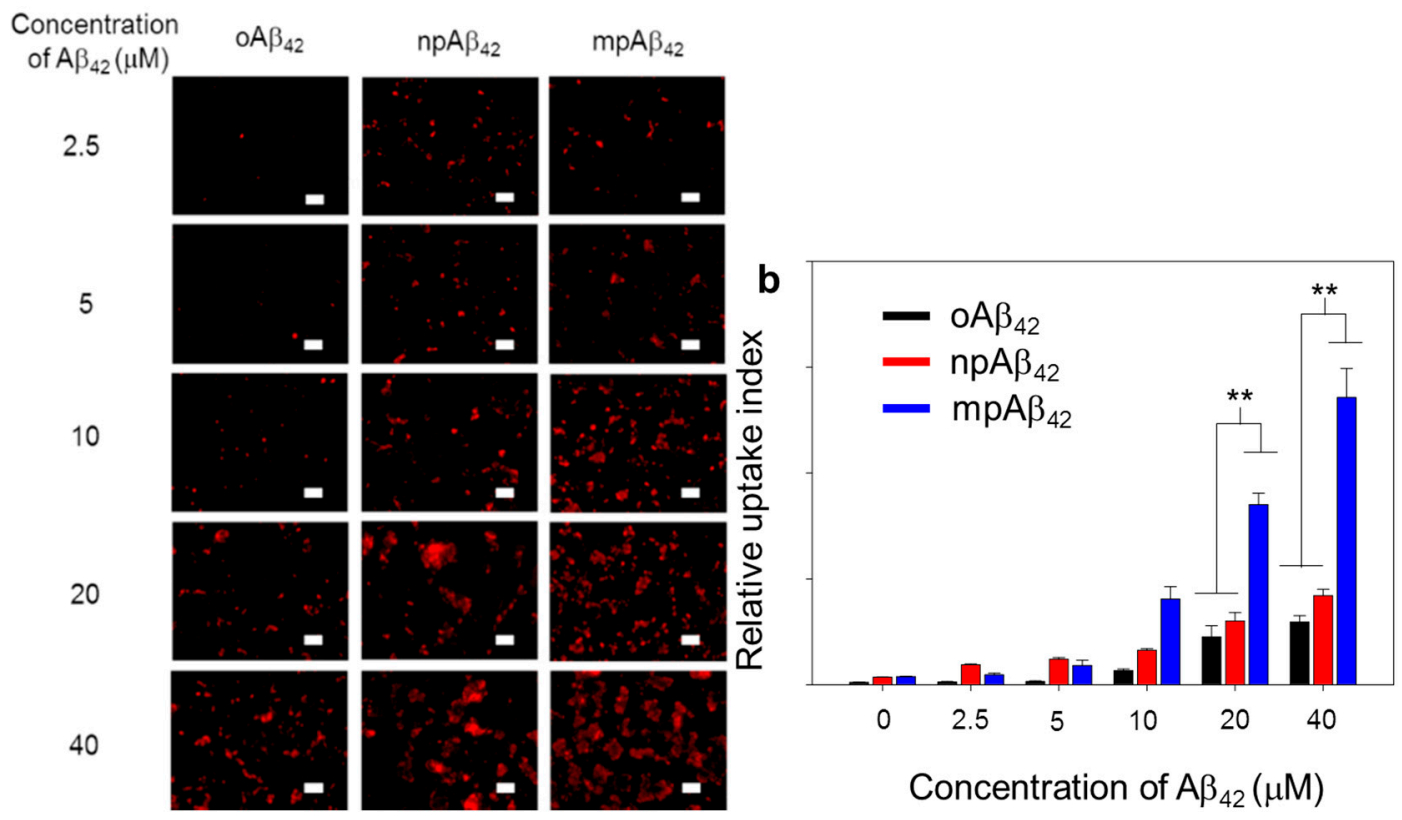

Figure 7. Phagocytic action of BV-2 cells. (a) Laser scanning confocal microscope (LSCM) images of BV-2 cells after co-incubation with oA $\beta_{42}, n p A \beta_{42}$, and mpA $\beta_{42}$, respectively $(n=8)$. A $\beta_{42}$ in different forms was IHC stained using 6 E10 as the primary antibody $\left(\lambda_{\mathrm{ex}}=565 \mathrm{~nm}, \lambda_{\mathrm{em}}=680-730 \mathrm{~nm}\right)$. Scale bar: $50 \mu \mathrm{m}$. (b) Relative uptake index of $\mathrm{A} \beta_{42}$ by BV-2 cells. One-way ANOVA was used to examine the mean differences between the end points of the data groups. ${ }^{* *} p<0.01$. Error bars represent mean \pm s.d. $(n=8)$.

As shown in Figure $8 \mathrm{a}, \mathrm{b}$, the production of the pro-inflammatory cytokines such as IL-1 $\beta$ and TNF- $\alpha$ from microglial cells after uptake of $m p A \beta_{42}$ (or $n p A \beta_{42}$ ) was substantially reduced as compared to the uptake of oA $\beta_{42}$. This is also reflected by a significant increase in secretion of IL-10 (an anti-inflammatory cytokine) from microglial cells co-incubated with mpA $\beta_{42}$ (or npA $\beta_{42}$ ) aggregates as compared to oA $\beta_{42}$ species (Figure 8c). Comparing the differences in the levels of both pro-inflammatory cytokines and anti-inflammatory cytokines from microglia treated with oA $\beta_{42}$ species and plaques $\left(\operatorname{mpA} \beta_{42}\right.$ and npA $\left.\beta_{42}\right)$, respectively, the extent of the $\mathrm{oA} \beta_{42}$-induced polarization of microglia to $\mathrm{M} 1$ type was reduced for the run with oA $\beta_{42}$ being captured and transformed into $\operatorname{mpA} \beta_{42}$ (or $n p A \beta_{42}$ ) via the magnetic stirring treatment. With the decreased pro-inflammatory cytokines and the increased anti-inflammatory cytokines, the neuroinflammation as one of the AD causes is thus greatly reduced. As shown in Figure S11, a significant difference in the viability of $\mathrm{N} 2$ a cells after $24 \mathrm{~h}$ incubation in conditioned media collected separately from the co-incubations of BV-2 cells with oA $\beta_{42}$ and those with $\mathrm{mpA} \beta_{42}$ was observed. Owing to the reduced inflammatory responses, the viability of the neuron cells in conditioned medium from the co-incubation of BV-2 cells with the stirring-induced $\mathrm{A} \beta_{42}$ aggregates was thus promoted. These data strongly imply that the magnetic stirring treatment is capable of effectively reducing neuroinflammation, thereby leading to a pronounced increase in the survival of N2a cells. In addition, the preliminary in vivo study showed no obvious tissue damage with the brain receiving the MSB stirring treatment (Figure S12a). The MSBs were mostly degraded over 15 days after the intrahippocampal injection (Figure S12b). No significant increases in cell apoptosis and ROS generation were found from the staining of the brain tissues with 
caspase 3 marker and with SOSG in the treated mice compared to the control group (Figure S12c). These results further demonstrated the safety and feasibility of this novel approach in practical applications for the AD treatment.

a

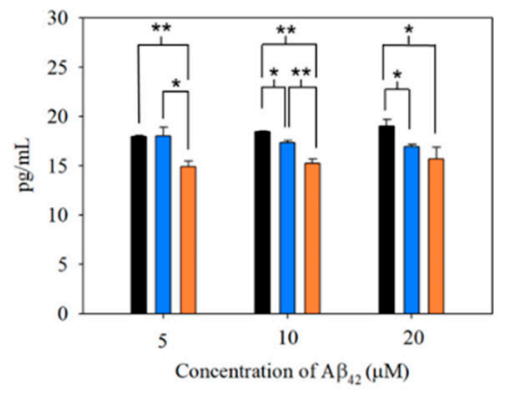

b

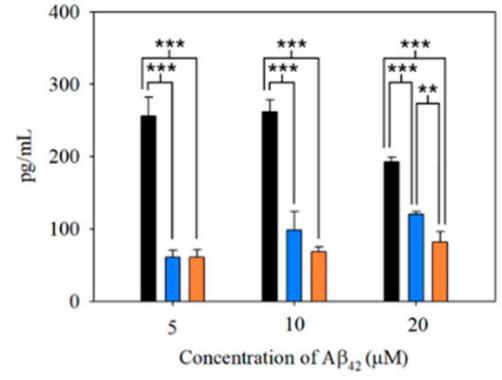

C

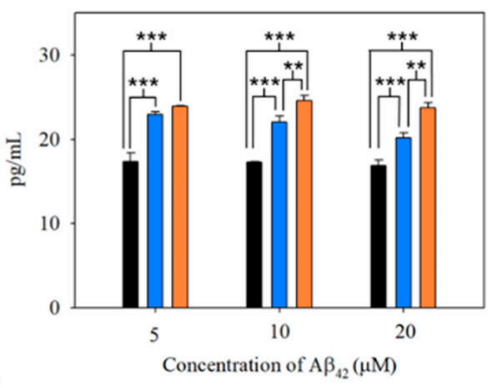

Figure 8. Cytokine secretion from BV-2 cells treated with oA $\beta_{42}, \operatorname{mpA} \beta_{42}$, and $n p A \beta_{42}$, respectively, for $6 \mathrm{~h}$. Concentrations of IL-1 $\beta$ (a), TNF- $\alpha$ (b), and IL-10 (c) were determined in triplicate wells by ELISA analyses. The experiments were independently repeated three times and one-way ANOVA was used to examine the mean differences between the data groups. ${ }^{* *} p<0.005,{ }^{* *} p<0.01,{ }^{*} p<0.05$, and N.S. $p>0.05$. Error bars represent mean \pm s.d. $(n=3)$.

\section{Conclusions}

In this work, we have demonstrated the successful development of the MSB-stirring based AD therapy system for rapid effective capture of oA $\beta_{42}$ species that are subsequently transformed into large magnetic aggregates $\left(\mathrm{mpA}_{42}\right)$ in vitro. In this manner, the neurotoxicity of oA $\beta_{42}$ against neuronal cells and the oA $\beta_{42}$-induced polarization of microglia to M1 type characterized by high pro-inflammatory propensity can be significantly reduced. Through the increased close contact among $\mathrm{oA} \beta_{42}$ species by stirring and magnetic attraction of MSB-entrapped oA $\beta_{42}$ aggregates under rotating magnetic field, rapid effective conversion of neurotoxic oA $\beta_{42}$ species into harmless mpA $\beta_{42}$ can be achieved. The MSB therapy system not only exhibits negligible cytotoxicity toward neuronal cells in the absence or presence of rotating magnetic field, but also greatly reduces the neurotoxicity of $\mathrm{oA} \beta_{42}$ by rapid capture of oA $\beta_{42}$ species into $\mathrm{mpA} \beta_{42}$ aggregates even with a concentration at $0.3 \mu \mathrm{M}$. The magnetic stirring treatment has shown a superior capability of maintaining the functionality of N2a cells in viability, specific protein expression and neurite outgrowth, and reducing the levels of pro-inflammatory cytokines secreted from M1 type microglial cells due to the effective agglutination of toxic oA $\beta_{42}$ species into mpA $\beta_{42}$. With the limited polarization of microglia into M1 type, the effective clearance of $\mathrm{mpA} \beta_{42}$ via the phagocytosis of microglia was achieved. The brain tissue histologic study showed no obvious tissue damage with the mice receiving the MSB stirring treatment in the hippocampus area. Neither cell apoptosis nor ROS generation in the brain tissues were found to be significantly increased. The MSBs were extensively degraded over 15 days after the intracranial injection. These results strongly suggest that the magnetic stirring treatment with MSBs be a promising strategy for improving the AD treatment. Further detailed studies concerning the in vivo therapeutic efficacy of the MSB stirring treatment against AD is in progress.

Supplementary Materials: The following are available online at http://www.mdpi.com/2079-4991/10/7/1284/s1. Figure S1: Characterization of SPIONs. (a) TEM image of OA-SPIONs and (b) TEM image of LA/OA-SPIONs. Scale bar: $50 \mathrm{~nm}$. (c) TGA measurement of OA-SPIONs. (d) Field-dependent magnetic curves of OA-SPIONs (black line) and LA/OA-SPIONs (red line) measured at the same Fe concentration. (e) XRD patterns of OA-SPIONs and LA/OA-SPIONs. Figure S2: Alignment of MSBs examined by optical microscopy. (a) The random localization of MSBs in the absence of external magnet. (b) Uniform alignment of MSBs in accordance to the magnet (black arrows). (c) Dispersion of rhodamine B in water droplets by magnetic stirring with MSBs under rotating magnetic field. Figure S3: Colloidal stability over $120 \mathrm{~min}$ in different aqueous milieus. Count rates of MSBs in DI water (-), DMEM (-), DMEM containing 10\% FBS (-) and PBS (-) at different time intervals with various magnetic stirring speeds: (a) 0, (b) 500, (c) 1500 and (d) $2500 \mathrm{rpm}$. Error bars represent mean \pm s.d. $(n=6)$. Figure S4: 
Pronounced effect of capturing oA $\beta_{42}$ by magnetic stirring ( $2500 \mathrm{rpm}$ ) with MSBs $(144 \mu \mathrm{g} / \mathrm{mL})$ into aggregates was observed by $\operatorname{LSCM}(n=10)$. The $\mathrm{oA} \beta_{42}$ was stained with ThT and CR. Scale bar: $100 \mu \mathrm{m}$. Figure S5: Detailed structural characterizations of $n p A \beta_{42}$. (a) Fluorescence intensity of ThT in aqueous solution of $A \beta_{42}(20 \mu \mathrm{M})$ as a function of time. (b) CR absorption spectra $(420-580 \mathrm{~nm})$ of $A \beta_{42}(20 \mu \mathrm{M})$ with different incubation time intervals. (c) TEM and HR-TEM images of oA $\beta_{42}$. (d) TEM and HR-TEM images of npA $\beta_{42}$. Figure S6: Capture of npA $\beta_{42}$ into large aggregates by MSB stirring $(n=10)$. (a) Fluorescence images of $n p A \beta_{42}$ treated with magnetic stirring as a function of the concentration of MSBs at $2500 \mathrm{rpm}$ for $20 \mathrm{~min}$. The $\mathrm{A} \beta_{42}$ concentration was $20 \mu \mathrm{M}$. The npA $\beta_{42}$ was attained from incubation of $\mathrm{oA} \beta_{42}$ in PBS under mild shaking at $37^{\circ} \mathrm{C}$ for 7 days. Scale bar: $100 \mu \mathrm{m}$. (b) Total signal areas of large aggregates by ThT and CR staining. ${ }^{* *} p<0.005,{ }^{* *} p<0.01,{ }^{*} p<0.05$ and N.S. $p>0.05$. Error bars represent mean \pm s.d. $(n=10)$. Figure S7: (a) LSCM images of the neuron (N2a) outgrowth with magnetic stirring of various speeds for $2 \mathrm{~h}\left(\mathrm{MSB} 144 \mu \mathrm{g} \mathrm{mL}^{-1}\right)$. Cytoskeleton was stained with F-actin marker. Scale bar: $100 \mu \mathrm{m}$. The viability of N2a cells receiving the magnetic stirring treatment with MSBs $\left(144 \mu \mathrm{gL} \mathrm{mL}^{-1}\right)$ at various stirring speeds. (b) Cell viability of $\mathrm{N} 2 \mathrm{a}$ cells after the capture of $\mathrm{oA} \beta_{42}$ by magnetic stirring with MSBs of different concentrations at $2500 \mathrm{rpm}$ for preset time intervals. The cell viability was evaluated by MTT assay. Error bars represent mean \pm s.d. $(n=6)$. Figure S8: Representative LSCM images of N2a cells before and after the magnetic stirring treatment. LSCM images of N2a cells treated with either oA $\beta_{42}$ only or oA $\beta_{42} / \mathrm{MSBs}$ (oA $\beta_{42}$ concentration: $160 \mu \mathrm{M}$; MSB $144 \mu \mathrm{g} \mathrm{mL}{ }^{-1}$ ) with and without magnetic stirring (2500 rpm) for $2 \mathrm{~h}(n=6)$. The cell nuclei and cytoskeleton were stained with Hoechst 33342 and F-actin marker, respectively. Scale bar: $50 \mu \mathrm{m}$. Quantitative data of neurite length $(\mu \mathrm{m})$ and number with and without magnetic stirring treatment are also included. ${ }^{* * *} p<0.005$. Error bars represent mean \pm s.d. $(n=6)$. Figure S9: Neuron-specific protein expression of $\mathrm{N} 2 \mathrm{a}$ cells treated either with $n p A \beta_{42}$ or $\operatorname{mpA} \beta_{42}(n=3)$. (a) Effects of $n p A \beta_{42}$ and mpA $\beta_{42}$ on neuron-specific protein expression (MAP2a/MAP2b, MAP2c, NF-M and NeuN). $\beta$-actin was used as the loading control. (b) Relative signal intensities of individual neuron-specific proteins from N2a cells after the npA $\beta_{42}$ or mpA $\beta_{42}$ treatment. The $A \beta_{42}$ concentration was $160 \mu \mathrm{M} .{ }^{*} p<0.05$. Error bars represent mean \pm s.d. $(n=3)$. Figure S10: Phagocytic actions of BV-2 cells toward oA $\beta_{42}, n p A \beta_{42}$ and $\mathrm{mpA} \beta_{42}$. Representative LSCM images of the $\mathrm{A} \beta_{42}$ uptake by BV-2 cells $(n=8)$. $\mathrm{A} \beta_{42}$ in different forms was IHC-stained using $6 \mathrm{E} 10$ as the primary antibody $(\lambda \mathrm{ex}=565 \mathrm{~nm}, \lambda \mathrm{em}=680-730 \mathrm{~nm})$. Cell nuclei and cytoskeleton were stained with Hoechst 33342 and F-actin marker, respectively. Scale bar: $50 \mu \mathrm{m}$. Figure S11: Cell viability of N2a cells after 24 h-incubation in conditioned media collected separately from the co-incubations of BV-2 cells with oA $\beta_{42}$ and BV-2 cells with $\operatorname{mpA} \beta_{42}{ }^{* * *} p<0.005,{ }^{* *} p<0.01$. Error bars represent mean \pm s.d. $(n=6)$. Figure S12: Brain tissue examination with (a) H\&E (b) prussian blue (MSBs) and (c) DAPI (nuclei), SOSG (ROS) and caspase-3 (cell apoptosis) IHC staining from healthy C57BL/6J mice receiving MSB stirring treatment $(2400 \mathrm{rpm}, 20 \mathrm{~min})(n=3)$. Scale bars for (a) and (b): $500 \mu \mathrm{m}$. Scale bar for (c): $100 \mu \mathrm{m}$. Table S1: Characterization of OA-SPIONs and LA/OA-SPIONs by DLS. Video S1: Magnetic sitrring of MSBs recorded by charged-coupled device (CCD) video camera. Vidoe S2: The blinking phenomenon caused by light scattering with MSB stirring recorded by charged-coupled device (CCD) video camera.

Author Contributions: Y.-C.T., J.-C.L., T.-I.L., and H.-C.C. conceived and designed the experiments. C.-Y.C. provided the materials and coordinated the western blotting study. J.-C.L. prepared the materials and carried out the experiments. Y.-C.T., C.-S.C., and H.-C.C. co-wrote the manuscript. M.-Y.S. and I.-L.L. participated data analyses and discussion. All authors discussed the results and commented on the manuscript. All authors have read and agreed to the published version of the manuscript.

Funding: This work is supported by the Ministry of Science and Technology, Taiwan (MOST 108-2314-B-007004-MY3 and MOST 107-2221-E-007-032-MY3); the National Tsing Hua University (109Q2520E1); Hsinchu Mackay Memorial Hospital, Taiwan (MMHTH-TH-10905); and China Medical University Hsinchu Hospital (CMUHCH-DMR-109-006), Taiwan.

Conflicts of Interest: The authors declare no competing interests.

\section{References}

1. Klein, W.L.; Krafft, G.A.; Finch, C.E. Targeting small Abeta oligomers: The solution to an Alzheimer's disease conundrum? Trends Neurosci. 2001, 24, 219-224. [CrossRef]

2. Maia, M.A.; Sousa, E. BACE-1 and $\gamma$-secretase as therapeutic targets for Alzheimer's disease. Pharmaceuticals 2019, 12, 41. [CrossRef] [PubMed]

3. Cummings, J.; Lee, G.; Ritter, A.; Sabbagh, M.; Zhong, K. Alzheimer's disease drug development pipeline: 2019. Alzheimers Dement. 2019, 5, 272-293. [CrossRef]

4. Panza, F.; Lozupone, M.; Logroscino, G.; Imbimbo, B.P. A critical appraisal of amyloid- $\beta$-targeting therapies for Alzheimer disease. Nat. Rev. Neurol. 2019, 15, 73-88. [CrossRef] [PubMed]

5. Doody, R.S.; Thomas, R.G.; Farlow, M.; Iwatsubo, T.; Vellas, B.; Joffe, S.; Kieburtz, K.; Raman, R.; Sun, X.; Aisen, P.S. Phase 3 trials of Solanezumab for mild-to-moderate Alzheimer's disease. N. Engl. J. Med. 2014, 370, 311-321. [CrossRef] [PubMed] 
6. Lauren, J.; Gimbel, D.A.; Nygaard, H.B.; Gilbert, J.W.; Strittmatter, S.M. Cellular prion protein mediates impairment of synaptic plasticity by amyloid-beta oligomers. Nature 2009, 457, 1128-1132. [CrossRef] [PubMed]

7. Zhang, Y.; Zhao, Y.; Zhang, L.; Yu, W.; Wang, Y.; Chang, W. Cellular prion protein as a receptor of toxic amyloid- $\beta 42$ oligomers is important for Alzheimer's disease. Front. Cell Neurosci. 2019, 13, 339. [CrossRef]

8. EI-Shimy, I.A.; Heikal, O.A.; Hamdi, N. Minocycline attenuates A $\beta$ oligomers-induced pro-inflammatory phenotype in primary microglia while enhancing A $\beta$ fibrils phagocytosis. Neurosci. Lett. 2015, 609, $36-41$. [CrossRef]

9. Cherry, J.D.; Olschowka, J.A.; O'Banion, M.K. Neuroinflammation and M2 microglia: The good, the bad, and the inflamed. J. Neuroinflamm. 2014, 11, 98. [CrossRef]

10. Block, M.L.; Hong, J.S. Microglia and inflammation-mediated neurodegeneration: Multiple triggers with a common mechanism. Prog. Neurobiol. 2005, 76, 77-98. [CrossRef]

11. Tobinick, E.L.; Gross, H. Rapid cognitive improvement in Alzheimer's disease following perispinal etanercept administration. J. Neuroinflamm. 2008, 5, 2. [CrossRef] [PubMed]

12. De Felice, F.G.; Ferreira, S.T. Inflammation, defective insulin signalling, and mitochondrial dysfunction as common molecular denominators connecting type 2 diabetes to Alzheimer disease. Diabetes 2014, 63, 2262-2272. [CrossRef] [PubMed]

13. Lee, C.Y.; Landreth, G.E. The role of microglia in amyloid clearance from the AD brain. J. Neural Transm. 2010, 117, 949-960. [CrossRef]

14. Yang, W.; Wu, Q.; Yuan, C.; Gao, J.; Xiao, M.; Gu, M.; Ding, J.; Hu, G. Aquaporin-4 mediates astrocyte response to $\beta$-amyloid. Cell Neruosci. 2012, 49, 406-414. [CrossRef] [PubMed]

15. Kanekiyo, T.; Cirrito, J.R.; Liu, C.C.; Shinohara, M.; Li, J.; Schuler, D.R.; Shinohara, M.; Holtzman, D.M.; Bu, G. Neuronal clearance of amyloid- $\beta$ by endocytic receptor LRP1. J. Neurosci. 2013, 33, 19276-19283. [CrossRef]

16. Tang, Y.; Le, W. Differential roles of M1 and M2 microglia in neurodegenerative diseases. Mol. Neurobiol. 2016, 53, 1181-1194. [CrossRef]

17. Winkler, E.; Julius, A.; Steiner, H.; Langosch, D. Homodimerization protects the amyloid precursor protein C99 fragment from cleavage by $\gamma$-secretase. Biochemistry 2015, 54, 6149-6152. [CrossRef]

18. Parajuli, B.; Sonobe, Y.; Horiuchi, H.; Takeuchi, H.; Mizuno, T.; Suzumura, A. Oligomeric amyloid $\beta$ induces IL-1 $\beta$ processing via production of ROS: Implicationin Alzheimer's disease. Cell Death Dis. 2013, 4, e975. [CrossRef]

19. Prade, E.; Barucker, C.; Sarkar, R.; Althoff-Ospelt, G.; Lopez del Amo, J.M.; Hossain, S.; Zhong, Y.; Multhaup, G.; Reif, B. Sulindac sulfide induces the formation of large oligomeric aggregates of the Alzheimer's disease amyloid- $\beta$ peptide which exhibit reduced neurotoxicity. Biochemistry 2016, 55, 1839-1849. [CrossRef]

20. Bieschke, J.; Herbst, M.; Wiglenda, T.; Friedrich, R.P.; Boeddrich, A.; Schiele, F.; Kleckers, D.; Lopez del Amo, J.M.; Gruning, B.A.; Wang, Q.; et al. Small-molecule conversion of toxic oligomers to nontoxic $\beta$-sheet-rich amyloid fibrils. Nat. Chem. Biol. 2011, 8, 93-101. [CrossRef]

21. Keskin, A.D.; Kekus, M.; Adelsberger, H.; Neumann, U.; Shimshek, D.R.; Song, B.; Zott, B.; Peng, T.; Forstl, H.; Staufenbiel, M.; et al. BACE inhibition-dependent repair of Alzheimer's pathophysiology. Proc. Natl. Acad. Sci. USA 2017, 114, 8631-8636. [CrossRef] [PubMed]

22. Meier, S.R.; Syvanen, S.; Hultgvist, G.; Fang, X.T.; Roshanbin, S.; Lannfelt, L.; Neumann, U.; Sehlin, D. Antibody-based in vivo PET imaging detects amyloid- $\beta$ reduction in Alzheimer transgenic mice after BACE-1 inhibition. J. Nucl. Med. 2018, 59, 1885-1891. [CrossRef] [PubMed]

23. Huang, W.C.; Lu, I.L.; Chiang, W.H.; Lin, Y.W.; Tsai, Y.C.; Chen, H.H.; Chang, C.W.; Chiang, C.S.; Chiu, H.C. Tumortropic adipose-derived stem cells carrying smart nanotherapeutics for targeted delivery and dual-modality therapy of orthotopic glioblastoma. J. Control Release 2017, 254, 119-130. [CrossRef]

24. Hu, Y.; He, L.; Yin, Y. Magnetically responsive photonic nanochains. Angew. Chem. Int. Ed. Engl. 2011, 50, 3747-3750. [CrossRef]

25. Dahlgren, K.N.; Manelli, A.M.; Stine, W.B., Jr.; Baker, L.K.; Krafft, G.A.; LaDu, M.J. Oligomeric and fibrillar species of amyloid-beta peptides differentially affect neuronal viability. J. Biol. Chem. 2002, 277, 32046-32053. [CrossRef] [PubMed]

26. Lambert, M.P.; Viola, K.L.; Chromy, B.A.; Chang, L.; Morgan, T.E.; Yu, J.; Venton, D.L.; Krafft, G.A.; Finch, C.E.; Klein, W.L. Vaccination with soluble Abeta oligomers generates toxicity-neutralizing antibodies. J. Neurochem. 2001, 79, 595-605. [CrossRef] 
27. Kuznetsova, I.M.; Sulatskaya, A.I.; Uversky, V.N.; Turoverov, K.K. Analyzing thioflavin T binding to amyloid fibrils by an equilibrium microdialysis-based technique. PLOS ONE 2012, 7, e30724. [CrossRef]

28. Hudson, S.A.; Ecroyd, H.; Kee, T.W.; Carver, J.A. The thioflavin T fluorescence assay for amyloid fibril detection can be biased by the presence of exogenous compounds. FEBS J. 2009, 276, 5960-5972. [CrossRef]

29. Huang, C.; Xu, D.; Zhang, K.; Shentu, J.; Yan, S.; Wu, D.; Wang, Q.; Cui, W. A11-positive $\beta$-amyloid oligomer preparation and assessment using dot blotting analysis. J. Vis. Exp. 2018, 135, 57592.

30. Xue, C.; Tran, J.; Wang, H.; Park, G.; Hsu, F.; Guo, Z. A $\beta_{42}$ fibril formation from predominantly oligomeric samples suggests a link between oligomer heterogeneity and fibril polymorphism. R. Soc. Open Sci. 2019, 6, 190179. [CrossRef]

31. Chowdhury, S.R.; Mondal, S.; Muthuraj, B.; Balaji, S.N.; Trivedi, V.; Iyer, P.K. Remarkably efficient blood-brain barrier crossing polyfluorene-chitosan nanoparticle selectively tweaks amyloid oligomer in cerebrospinal fluid and $\mathrm{A} \beta_{1-40}$. ACS Omega 2018, 3, 8059-8066. [CrossRef] [PubMed]

32. Sun, L.; Zhong, Y.; Gui, J.; Wang, X.; Zhuang, X.; Weng, J. A hydrogel biosensor for high selective and sensitive detection of amyloid-beta oligomers. Int. J. Nanomed. 2018, 13, 843-856. [CrossRef] [PubMed]

33. Fischer, D.; Li, Y.; Ahlemeyer, B.; Krieglstein, J.; Kissel, T. In vitro cytotoxicity testing of polycations: Influence of polymer structure on cell viability and hemolysis. Biomaterials 2003, 24, 1121-1131. [CrossRef]

34. Wang, W.; Hou, T.T.; Jia, L.F.; Wu, Q.Q.; Quan, M.N.; Jia, J.P. Toxic amyloid- $\beta$ oligomers induced self-replication in astrocytes triggering neuronal injury. EBioMedicine 2019, 42, 174-187. [CrossRef] [PubMed]

35. Chakrabarty, P.; Tianbai, L.; Herring, A.; Ceballos-Diaz, C.; Das, P.; Golde, T.E. Hippocampal expression of murine IL-4 results in exacerbation of amyloid deposition. Mol. Neurodegener. 2012, 7, 36. [CrossRef] [PubMed]

36. Jean, Y.Y.; Baleriola, J.; Fa, M.; Hengst, U.; Troy, C.M. Stereotaxic infusion of oligomeric amyloid-beta into the mouse hippocampus. J. Vis. Exp. 2015, 100, e52805. [CrossRef]

37. Chong, W.H.; Chin, L.K.; Tan, R.L.; Wang, H.; Liu, A.Q.; Chen, H. Stirring in suspension: Nanometer-sized magnetic stir bars. Angew. Chem. Int. Ed. Engl. 2013, 33, 8570-8573. [CrossRef]

38. Malvindi, M.A.; De Matteis, V.; Galeone, A.; Brunetti, V.; Anyfantis, G.C.; Athanassiou, A.; Cingolani, R.; Pompa, P.P. Toxicity assessment of silica coated iron oxide nanoparticles and biocompatibility improvement by surface engineering. PLoS ONE 2014, 9, e85835. [CrossRef]

39. Younan, N.D.; Viles, J.H. A comparison of three fluorophores for the detection of amyloid fibers and prefibrillar oligomeric assemblies. ThT (Thioflavin T); ANS (1-Anilinonaphthalene-8-sulfonic Acid); and bisANS (4,4'-Dianilino-1,1'-binaphthyl-5,5'-disulfonic Acid). Biochemistry 2015, 54, 4297-4306. [CrossRef]

40. Biancalana, M.; Koide, S. Molecular mechanism of Thioflavin-T binding to amyloid fibrils. Biochim. Biophys. Acta 2010, 1804, 1405-1412. [CrossRef]

41. Stsiapura, V.I.; Maskevich, A.A.; Kuzmitsky, V.A.; Turoverov, K.K.; Kuznetsova, I.M. Computational study of thioflavin T torsional relaxation in the excited state. J. Phys. Chem. A 2007, 111, 4829-4835. [CrossRef] [PubMed]

42. Xue, C.; Lin, T.Y.; Chang, D.; Guo, Z. Thioflavin T as an amyloid dye: Fibril quantification, optimal concentration and effect on aggregation. R. Soc. Open Sci. 2017, 4, 160696. [CrossRef] [PubMed]

43. Frid, P.; Anisimov, S.V.; Popovic, N. Congo red and protein aggregation in neurodegenerative diseases. Brain Res. Rev. 2007, 53, 135-160. [CrossRef] [PubMed]

44. Meehan, S.; Berry, Y.; Luisi, B.; Dobson, C.M.; Carver, J.A.; MacPhee, C.E. Amyloid fibril formation by lens crystallin proteins and its implications for cataract formation. J. Biol. Chem. 2004, 279, 3413-3419. [CrossRef] [PubMed]

45. Sengupta, U.; Nilson, A.N.; Kayed, R. The Role of amyloid- $\beta$ oligomers in toxicity, propagation, and immunotherapy. EBioMedicine 2016, 6, 42-49. [CrossRef]

46. Kayed, R.; Lasagna-Reeves, C.A. Molecular mechanisms of amyloid oligomers toxicity. J. Alzheimers Dis. 2013, 33, 67-78. [CrossRef]

47. Kumar, S.; Wirths, O.; Stuber, K.; Wunderlich, P.; Koch, P.; Theil, S.; Rezaei-Ghaleh, N.; Zweckstetter, M.; Bayer, T.A.; Brustle, O.; et al. Walter, Phosphorylation of the amyloid $\beta$-peptide at Ser26 stabilizes oligomeric assembly and increases neurotoxicity. Acta Neuropathol. 2016, 131, 525-537. [CrossRef]

48. Benilova, I.; Karran, E.; De Strooper, B. The toxic A $\beta$ oligomer and Alzheimer's disease: An emperor in need of clothes. Nat. Neurosci. 2012, 15, 349-357. [CrossRef] 
49. Doi, Y.; Mizuno, T.; Maki, Y.; Jin, S.; Mizoguchi, H.; Ikeyama, M.; Doi, M.; Michikawa, M.; Takeuchi, H.; Suzumura, A. Microglia activated with the toll-like receptor 9 ligand CpG attenuate oligomeric amyloid \{beta\} neurotoxicity in in vitro and in vivo models of Alzheimer's disease. Am. J. Pathol. 2009, 5, 2121-2132. [CrossRef]

50. Suzumura, A. Neurotoxicity by microglia: The mechanisms and potential therapeutic strategy. Fukuoka Igaku Zasshi 2009, 1, 243-247.

51. Richard, K.L.; Filali, M.; Prefontaine, P.; Rivest, S. Toll-like receptor 2 acts as a natural innate immune receptor to clear amyloid beta 1-42 and delay the cognitive decline in a mouse model of Alzheimer's disease. J. Neurosci. 2008, 28, 5784-5793. [CrossRef] [PubMed]

52. Tahara, K.; Kim, H.D.; Jin, J.J.; Maxwell, J.A.; Li, L.; Fukuchi, K. Role of toll-like receptor signalling in Abeta uptake and clearance. Brain 2006, 129, 3006-3019. [CrossRef] [PubMed]

53. Fujikura, M.; Iwahara, N.; Hisahara, S.; Kawamata, J.; Matsumura, A.; Yokokawa, K.; Saito, T.; Manabe, T.; Matsushita, T.; Suzuki, S.; et al. CD14 and toll-like receptor 4 promote fibrillar A $\beta_{42}$ uptake by microglia through a clathrin-mediated pathway. J. Alzheimers Dis. 2019, 68, 323-337. [CrossRef] [PubMed]

54. Geloso, M.C.; Corvino, V.; Marchese, E.; Serrano, A.; Michetti, F.; D'Ambrosi, N. The dual role of microglia in ALS: Mechanisms and therapeutic approaches. Front. Aging Neurosci. 2017, 9, 242. [CrossRef]

(C) 2020 by the authors. Licensee MDPI, Basel, Switzerland. This article is an open access article distributed under the terms and conditions of the Creative Commons Attribution (CC BY) license (http://creativecommons.org/licenses/by/4.0/). 